\title{
LA DECONVENUE
}

C'est le nadir après la nava

$C^{\prime}$ 'est $I^{\prime}$ attaque sans avertissement Quand la chimère vous choque La plaie est la torpeur

C'était la trahison avec raison

Encore le noctambulisme

Diane Powers

The University of Kansas 